University of Northern Colorado

Scholarship \& Creative Works @ Digital UNC

$1-1-2009$

The Relationship Between Service Learning and Research

Jennifer Nutefall

Follow this and additional works at: https://digscholarship.unco.edu/libfacpub

Part of the Library and Information Science Commons 


\section{The Relationship Between Service Learning and Research}

Public Services Quarterly

2009

Nutefall, Jennifer E.

OSU Libraries, Oregon State University

This is the author's peer-reviewed final manuscript, as accepted by the publisher. The published article is copyrighted by Taylor \& Francis and can be found at:

http://www.tandfonline.com/toc/wpsq20/current.

Citation: Nutefall, J. E. (2009). The relationship between service learning and research [Electronic version]. Public Services Quarterly, 5(4), 250-261. doi:10.1080/15228950903199271 
Running head: SERVICE LEARNING AND RESEARCH

The relationship between service learning and research

\begin{abstract}
In fall 2006 a faculty member in George Washington University’s University Writing 20 (UW20) program began incorporating service learning into her theme-based first-year writing course. Along with her librarian partner they linked two research assignments to the service work of the students. An end-of-semester survey was administrated over three semesters with one question asking if student's research process was affected by their service experience. In reviewing and analyzing student comments four themes emerged which are increased motivation, use of numerical data and primary sources, increased knowledge in approaching and limiting topics, and the potential for bias.
\end{abstract}


Running head: SERVICE LEARNING AND RESEARCH

The relationship between service learning and research

Jennifer E. Nutefall

\section{ABSTRACT}

In fall 2006 a faculty member in George Washington University's University Writing 20 (UW20) program began incorporating service learning into her theme-based first-year writing course. Along with her librarian partner they linked two research assignments to the service work of the students. An end-of-semester survey was administrated over three semesters with one question asking if student's research process was affected by their service experience. In reviewing and analyzing student comments four themes emerged which are increased motivation, use of numerical data and primary sources, increased knowledge in approaching and limiting topics, and the potential for bias.

KEYWORDS: Service learning, research, information literacy, motivation, collaboration

\section{INTRODUCTORY NOTE}

Jennifer Nutefall, MLS, is the Associate University Librarian for Innovative User Services at Oregon State University in Corvallis, OR and was previously Instruction Coordinator at George Washington University in Washington, DC.

Email: jennifer.nutefall@oregonstate.edu

Mailing address: 121 The Valley Library, Corvallis, OR 97331 


\section{Introduction}

Service learning is defined by Eyler (2002) as "an experimental learning pedagogy that balances the needs of student and community members involved, links the service and learning through reflective processes, and if skillfully managed leads to positive student personal, social or citizenship, career, and intellectual development" (p. 2205). Does incorporating service learning in a writing course change how students view research? At George Washington University (GWU) first-year students in the University Writing 20 (UW20) course titled "Public Writing" make connections between service learning, writing, and research. Professor Phyllis Ryder, who has taught UW20 since the program began in 2003, has been incorporating service learning since fall 2006. Students in Ryder's course work with one of six Washington, DC non-profit organizations related to homelessness, education, or the environment for a total of 20 hours over the course of the semester. The non-profit organizations serve as the basis for the writing assignments in the course leading students to investigate the rhetoric of the organization, research an issue related to the work of the organization, and produce a commissioned work for the organization. This article will touch upon the faculty/librarian collaboration in University Writing 20, describe two research assignments used in the course connected to student's service work, and identify four themes from student responses on an end-of-semester survey regarding their approach to research in a service learning course.

\section{Literature Review}

What is the importance of information literacy to service learning? One reason why librarians and faculty are interested in service learning is due to the research of Eyler and Giles (1999) who report that students understand a subject matter better when it is linked with service learning. In 
their key work Where's the Learning in Service Learning, the authors discuss the relationship of service learning to critical thinking and report on several studies that demonstrate this relationship. It is important for librarians to be aware of these studies as a way to increase the linkage between critical thinking and information literacy. In their summary on critical thinking and service learning, Eyler and Giles (1999) state that "service learning that is highly reflective and where course and community service are well integrated, has an impact on the quality of student thinking and problem solving" (p. 127).

While there is a growing interest in service learning there continues to be a gap in the library literature connecting service learning to information literacy. A key piece by Riddle (2003) begins by describing how "little has been written critically considering how service learning impacts the mission and services of college and university libraries" (p. 71). He then describes three options for how library instruction could look in a service learning course through the learning process, course objectives, and subject content models. Riddle (2003) argues "information seeking in a service learning pedagogy problematizes information literacy in up to three dimensions: the information needs of the student, the ideological objectives and structure of the practical class, and the subject matter/discipline being taught” (p. 75). He concludes his article by outlining a research agenda for service learning and information literacy.

Another article highlighting this literature gap is by Westney (2006) who discusses the engaged university which "links the differing perspectives of the dynamic partnerships that universities are forging with external constituencies to advance knowledge while building community through collaboration" (Westney, 2006, p. 200). How are libraries and librarians involved in building community? Westney (2006) describes the 2002-2005 Penn State University Libraries strategic planning document which included two goals for involving librarians in the community. 
This was continued in the 2005-2008 strategic plan in Initiative \#3 "which states that the development of ongoing ties with targeted community organizations is the focus and refers to specific partnerships" (Westney, 2006, p. 201). Yet she concludes by highlighting the lack of mention of libraries or librarians in the 2005 publication Service-learning in higher education. Westney (2006) encourages libraries to establish partnerships with community and national organizations to assist in educating civic minded students.

Articles that highlight collaborations between service learning and academic libraries include one written by Rhodes and Davis (2001) who describe a specific collaborative project between the library and a service learning English course at Hampton University. The students in the course produced brief research guides for the library which in turn were used by librarians in other instruction sessions and during freshmen and faculty orientation. The authors discuss the enthusiasm of the students who were learning new information and sharing it with their peers. Watts (2006) argues that integrating information literacy and service learning allows students to problem solve real life situations and engages them in their own learning. She highlights the Rainbow Advantage Program, a "tightly woven learning community based on the coordinated studies model" (p. 46). This program has been in place for over fourteen years and Watts (2006) highlights four projects that connect service learning with information literacy. Herther (2008) provides an overview of service learning and examples from her work with service learning courses at the University of Minnesota. She concludes by stating that service learning "provides a wonderful opportunity to expand and broaden our roles on campus; however, it also requires time and energy beyond that normally given to student support” (Herther, 2008, p. 389).

\section{University Writing 20}


UW20 is a theme-based, four-credit course required of all freshmen and each section is capped at 15 students. The theme based approach of the program is based on the "assumption that good writing and good research happen when students consider the writing/research process within a particular context, with a particular purpose, and with a particular audience" (Nutefall \& Ryder, 2006, p. 309). Every course is partnered with a librarian who works collaboratively with the writing professor to integrate information literacy appropriate to each course topic and to stress the point that expectations and processes of information literacy also are context-based concepts (Nutefall \& Ryder, 2006). Ryder and her partner librarian, Jennifer Nutefall, have collaborated since 2002 and served together on the campus-wide task force that developed the goals and implementation strategies for new writing program and specifically UW20. The faculty/librarian partnership is also emphasized on the First Year Writing Program (2008) web site:

Each section of UW20 is assigned a librarian from the Gelman Library System and assessments have shown that students profit from librarians' involvement by gaining the skills and confidence as researchers that will serve them well throughout their college career. As they participate in class sessions throughout the semester, librarians help students develop core information literacy skills, improving their ability to locate, evaluate, and use information as independent, life-long learners. Collaborating with the course instructor, the librarian conducts in-class sessions on various aspects of research, such as topic formulation, search strategy, and the evaluation of sources. In addition, the librarian may meet regularly with students in one-on-one and small group settings, to provide guidance as students work through their research projects (http://www.gwu.edu/ uwp/fyw/uw20-template.html). 


\section{Course Description}

At GWU first-year students sign up to take UW20 during either the fall or spring semester and students are encouraged to review course themes before registering for courses. The University Writing Program website provides information on each course offered which includes the date, time, and meeting location of the course as well as a detailed description of each course theme which is provided by the faculty member. In the fall of 2006, the first time Ryder incorporated service learning, her course description stated:

As part of our study of community organizations, you will read theories of social change, "special interest" groups and democracy, and the nature of the "public." You will test these theories by working with and observing community organizations in DC. And, finally, you will write about your findings for public audiences. Through this process, you will learn the power of writing and the ethical demands of writing about real issues for real people. This UW20 section includes a service learning component: as part of your course work, you will work in community organizations (University Writing Program, 2006).

After three semesters of working with the non-profit organizations and incorporating them into her course Ryder changed her course description to read:

What does it take to have a voice in public conversations, to shape the direction of our government or communities? Public writing means reaching out to strangers. It's about reason and research, yes; but it's also about creating hope and possibility. How can we do that? To find answers to these questions - and more! - we will study how it's done in 
local DC community organizations: what kind of public writing does it take to reclaim a park that was once given over to drug dealers, old tires, sewage? (Hint: Google Washington Parks and People.) What kind of public writing does it take to bring diverse neighbors together as a multicultural community? (Check out CentroNia.) What does it take to motivate inner-city sixth graders to spend their summers on more schoolwork? (Look up Higher Achievement Program.) In addition to reading, researching and writing about social change, you will volunteer weekly with local organizations. Writing and research assignments will focus on how organizations define issues, generate public interest, and make a difference. You will write for multiple audiences to see how those contexts shape writing choices (University Writing Program, 2007).

\section{Research and Writing Assignments}

There are two assignments that involve research. The first is an overview/analysis of the community organization in which students write a brief overview of the organization, the neighborhood it works in, and issues that the organization addresses. More recently this assignment has included a rhetorical analysis of the community organization in which students look for written, oral, and visual information to analyze the rhetoric of the organization. The first research session, held during week four, supported this assignment. Students were given a preassignment to look at the decennial population census using American Factfinder. Among the pieces of census data students looked at were educational attainment, income, race/ethnicity, and housing length of tenure. The census information is useful for students to see how the wards in DC differ. Students brought this information to class and a discussion took place about why certain pieces of information were important, what they might tell us about the people who live there, and clues to why the organization is working in a particular neighborhood. The discussion 
also allowed students to ask why they could not find certain pieces of information in the census such as religion and the number of homeless individuals. In addition to census information students searched for articles in the historical and current Washington Post for stories on their non-profit organization and articles on topics related to their organization. The newspaper stories were able to provide background information on how the organization has been covered in the media and the language used in stories about the organization and its issues.

The second assignment is a research analysis that asks students to take an aspect of their work with the community organization and enter the academic conversation around a particular issue. Students provide a complex understanding of the issue, discuss how well the academic research applies to the particular local context and may offer a particular solution. Before the second research session students posted a review of their experiences at the non-profit on Blackboard along with their reflection and included questions they were considering for their research paper and potential places to start. Both Ryder and Nutefall reviewed these reflections logs and responded to the students with thoughts on the potential topics as well as potential resources to consider. During the second research session, co-taught by Ryder and Nutefall, students focused on their research analysis topic and discussed disciplinarity and how different article databases covered issues in varying ways. This discussion started with students' thoughts about which disciplines would be interested in writing about their topic and how disciplines would be interested in different aspects. Using this discussion the class brainstormed potential keywords in small groups and then selected a subject specific database, such as ERIC, to search for articles on their topic. At the end of class students shared where they searched and the type of information they found and also followed up with postings on Blackboard. 
Nutefall's role in this course allowed her to get to know the students on a more individual level by reading through their service experiences on Blackboard, responding to their topic ideas, interacting with them in class, and responding to their individual questions over email. She also became informed on the community organizations, the type of work the organizations and students did, and was able to support the organizations through donations of needed supplies as well as money, such as buying the biweekly Street Sense, a newspaper that raises awareness on homelessness and poverty issues.

\section{Survey}

At the end of the fall 2006, spring 2007, and fall 2007 semesters 63 students in Ryder's course answered a survey on service learning developed by Ryder. The survey was intended to provide her with information to improve the course in future semesters. One of the seven questions asked focused on research. The question stated "Several research assignments in the course focused on your community organization. What research techniques did you use for those assignments? Did performing the research specifically about an organization with which you were volunteering affect your approach to the research process in any way? Please explain." Ryder shared the survey results with Nutefall as a way to reshape how research was integrated.

\section{Survey Results}

In analyzing student comments four main themes emerged (see Appendix for additional student comments). These themes were increased motivation, use of numerical data and primary sources, increased knowledge in approaching and limiting topics, and the potential for bias. Increased motivation for research was mentioned by 25 students making it the most frequent response. This was also a key point during the course of the semester. It was clear from in class discussions that 
students felt more connected to the research they were doing for their paper based on their personal experiences at their service site. For example one student decided to examine environmental racism based on her work with Washington Parks and People (WPP). She was interested in this topic based on her work with WPP and the placement of a waste site near DC's ward 7, which is a predominately black neighborhood. Her final project for WPP was assisting them in developing a curriculum that could be used in the neighborhood and the goal of her paper was if the park she worked in helped to change the image of the neighborhood from one of waste to one of renewal and outdoor activity.

Comments from the end of semester survey that focused on motivation highlighted the connection between the service learning and research for the analysis paper. There are two comments that are representative of students' motivation.

Student 1 - I did a lot of very heavy research on my topic because I wanted to be sure the material was good and what I was suggesting was accurate and informed, and I did a lot of this because I had a strong conviction on how I thought CentroNia should direct itself in the future to really fully complete the goals of social movement.

Student 2 - I wanted to motivate my readers to become more open minded to seeing the homeless and homelessness in a new light. Because I had such a positive experience with the program that changed many of my views for the better, my research focused on doing this for others.

Other comments on motivation focused on wanting to find more information based on their experience at the service site and how the papers they were writing had more meaning to them because of their connection to the organization. 
Another theme that emerged from the student comments was the use of traditional library resources but also the use of numerical data and primary sources in their paper. Sixteen student comments focused on this theme. Numerical data was used in a number of ways as with this student who commented "I studied specific demographics of Ward 7, and specific issues of racial inequalities and education, and how these all tie together and connect to HAP (Higher Achievement Program)." Several students commented on their use of interviews with members of their non-profit organization. A representative comment comes from this student who worked with a homeless organization and interviewed two of the leaders of the organization about their experiences. The student commented that this "affected the research process because it gave me instant access to actual people, as well as a more narrow range of topics to look at."

Sixteen student comments focused on their increased knowledge in approaching and limiting their topics. Their increased knowledge was based on their experiences at the non-profit site and made them more confident in sifting through their sources more critically. Students could better determine which sources really spoke to the specific issue they were asking allowing them to narrow the scope of their topic. Students frequently commented that by working with their organization they were more familiar with the issues and terminology around their topic. Two comments from the student survey highlight this point. The first student wrote that "By volunteering with the organization, I knew more about issues or areas that the organization deals with and it allowed me to explore more about what the organization does." Another student commented that by looking through the documents of their organization they found that "key terms began to show up in repetition, which I used to track down articles in online databases."

A fourth theme to emerge from the student comments was the potential for bias which was mentioned in seven student comments. Students were concerned about the potential to advocate 
for their non-profit organization in their papers. They also expressed a concern that they might only find information that supported a certain point of view. Two comments highlight this potential for bias. The first student wrote "in my situation I enjoyed attending HAP, and thus, I may have been somewhat biased towards the effectiveness of their parental involvement model." The caution of bias also was mentioned in this comment "after going there (CentroNia) every Saturday for a semester, I have grown to really admire the organization and what it does for its students. I'm sure this has led to my papers being somewhat biased in favor of CentroNia, as opposed to someone who had no involvement before conducting research.” There were also a small number of students who brought up the potential for bias then described how it made them more conscientious in their research. This led the students to investigate a person's views fully even those that disagreed with their argument.

\section{Conclusion}

The results from the survey allowed Nutefall and Ryder to identify specific changes that could be made to the course to better integrate research, while also highlighting some of the ways that research and service learning benefit students. Several changes were made to the research sessions based on results from the student survey. For the first research session the population census assignment was revised before every semester to allow students to make a better connection between the information found and its potential use in their paper. In later semesters students were directed to the District of Columbia webpage that compiled certain population census statistics instead of using American FactFinder through the population census website. A second change made for the first research session was compiling a brief selection of articles from the Washington Post on Miriam's Kitchen, one of the non-profits, which students read before class. This allowed Ryder and Nutefall to discuss both the content and language of the articles 
making a stronger connection to the first writing assignment. A third change related to the first research session was the inclusion of more local information sources such as the newspaper East of the River and transcripts from the Kojo Naambe radio show. This change assisted students in completing the first assignment by allowing them to investigate a wider range of potential sources to see how their organization and issue was covered. It also started a class discussion about why certain organizations and issues might be more prominent in local media than national media. A fourth change made was starting the second research session with a discussion of a course reading that focused on the idea of exploring many different disciplines to find information. This change made the research session more seamless and allowed the students to see connection between their course reading and their approach to research.

In addition to the specific course changes described, Nutefall's experience with the course helped her develop more general recommendations for librarians working with courses that incorporate service learning. Service learning courses offer many opportunities to integrate research and librarians working with courses that incorporate service learning should take the time to learn about the non-profit organizations and the areas they serve. This can be done through reading the organization's mission statement and web page, as well as finding information through local or national media. A better understanding of the non-profit organizations and their focus is beneficial for librarians as they will be more able to assist students with their assignments. It is also important for librarians working with service learning courses to have a good relationship with the faculty member teaching the course. This relationship can assist the librarian in better understanding the connection between the service experiences and the writing assignments and also allow for more collaboration in planning and teaching research sessions. Finally, it is useful for librarians to learn about students' service experiences either through in-class conversations or 
through online discussions through course management systems such as Blackboard. With this information librarians can better understand a student's interest in a particular topic, suggest books and articles to help them explore the topic further, and assist the student with making stronger connections between their service experience and their research.

Based on the results of this study the benefits for incorporating research into service learning courses are clear. Students had increased motivation for research, were exposed to a wider variety of source material, such as primary sources and numerical data, felt more knowledgeable in approaching and limiting their topics, and became more aware of the potential for bias. Incorporating research into the service learning course benefitted students in many ways, including enhancing the librarian's collaborative role in their work and providing opportunities for unique classroom discussion and writing experiences based on student's service experience. 


\section{References}

Eyler, J., \& Giles, D. E. (1999). Where's the learning in service learning? San Francisco, JosseyBass Publishers.

Eyler, J. (2002). Service learning: Higher education. In J. W. Guthrie (Ed.), Encyclopedia of education (Vol. 6, pp. 2205-2210). New York: Macmillian Reference USA.

First year writing. (2008). UW20 template. Retrieved May 22, 2009 from The George

Washington University, University Writing Program Web Site: http://www.gwu.edu/ uwp/fyw/uw20-template.html

Herther, N. K. (2008). Service learning and engagement in the academic library: Operating out of the box. C\&RL News, 69(7), 386-389.

Nutefall, J. E., \& Gaspar, G. (2008). Raise your profile: Build your program. Public Services Quarterly, 4(2), 127-135.

Nutefall, J., \& Mentzell Ryder, P. (2006). Teaching research rhetorically. Academic Exchange Quarterly, 9(4), 307-311.

Rhodes, N. J., \& Davis, J. M. (2001). Using service learning to get positive reactions in the library. Computers in Libraries, 21(1), 32-35.

Riddle, J. S. (2003). Where's the library in service learning?: Models for engaged library instruction. Journal of Academic Librarianship, 29(2), 71-81. 
University Writing Program. (2006, September 9). UW20 courses - Fall 2006. Retrieved May 7, 2009 from http://www.gwu.edu/ uwp/fyw/uw20-f06.html.

University Writing Program. (2007, September 9). UW20 courses - Fall 2007. Retrieved May 7 , 2009 from http://www.gwu.edu/ uwp/fyw/uw20-f07.html.

Watts, M. (2006). Becoming educated: Service learning as mirror. In C. Gibson (Ed.), Student engagement and information literacy (pp. 33-54). Chicago: American Library Association.

Westney, L. C. (2006). Conspicuous by their absence: Academic librarians in the engaged university. Reference \& User Services Quarterly, 45(3), 200-203. 


\section{Appendix}

\section{Sample Comments}

\section{Motivation}

I was more contentious of the research I was conducting because of the community organization - some of the research could support the organization and some could not, and I didn't want to degrade the organization with research.

I was much more driven to do research for papers and assignments because I felt that I had some investment in it. For my paper I wrote, I believed that I might be able to help the students that I was working with. To do research, knowing that it will be used to possibly help someone is much more fun than just doing research for the sake of writing a paper.

I felt like I had the similar experience - like there was more reason to do this research because you knew it could possibly do something. I did a lot of heavy research on my topic because I wanted to be sure the material was good and what I was suggesting was accurate and informed, and I did a lot of this because I had a strong conviction on how I thought CN (CentroNia) should direct itself in the future to really fully complete the goals of social movement.

I became much more invested in the assignments due to my involvement with DPHW (Dinner Program for Homeless Women). In terms of the research process, I was motivated to perform extremely thorough research, write many drafts to make my papers as good as they could possibly be, and even go over the page limit!

Volunteering with DPHW broke all the stereotypes that I previously held in my mind about homeless people. I developed relationships with many of the clients and really respected them. I 
think that this influenced my research process because I wanted to have a similar effect on my readers. At the least, I wanted to motivate my readers to become more open minded to seeing the homeless and homelessness in a new light.

I think focusing the research on Miriam's Kitchen made me want to do it and made me more curious. It really motivated me to try harder and discover more information.

\section{Primary Sources/Numerical Data}

By researching an organization that you are working directly with, you have easy access to information about the organization as well as potential interviewees.

I used a lot of online databases through the research portal of Gelman. An organization changed the way I researched because I had to look up specific facts about the community organization and used a lot more numerical data in addition to just journal articles.

Yes, this was definitely a new and interesting approach for me. I am used to working with textbooks, literature, and online sources, not pamphlets and handouts. It was cool to work with and analyze these types of sources.

\section{Authority}

By volunteering with the organization I knew more about issues or areas that the organization deals with and it allowed me to explore more about what the organization does. For example, instead of limiting my research to human services, I knew that my organization also dealt with anthropology, media, etc.

I was able to conduct my research on a more personal and in depth manner because I had a basis for what I was looking for and comparing in relation to CentroNia. Conducting this initial 
research on CentroNia sort of set up a little outline for me when conducting more general research because it allowed me to elaborate and look at the factors surrounding those of my community organization.

Researching HAP (Higher Achievement Program) just made me realize how important it is to get a lot of sources and weed out the ones which are not particularly important or relevant. HAP is a pretty specific organization and in researching HAP I had to find other sources of documents that connect to HAP's model or goals as an organization. Meeting in the library was helpful because it taught me how to get more specific in my research.

I definitely think that researching Miriam's Kitchen affected the way in which I approached researching for my analysis paper about public space. Examination of Miriam's Kitchen's programs facilitated my research in examining the ways other communities focus on the issue of homelessness.

The news articles gave initial background information about Washington Parks and People, specifically their evolution as a group and their involvement in the community. Through the perusal of these articles, key terms began to show up in repetition, which I used to track down articles in the online databases.

\section{Bias}

The only downside is that by working intimately with an organization you will definitely develop biases. The important thing is being AWARE of that bias when you are writing. In fact, now that I think of it, it's really not a downside. You are bound to develop a bias with most things you write. This experience helped me become more aware. 